DOI: $10.15193 /$ zntj/2017/113/214

\author{
MONIKA WESOŁOWSKA, MAŁGORZATA DŻUGAN
}

\title{
AKTYWNOŚĆ I STABILNOŚĆ TERMICZNA DIASTAZY WYSTĘPUJACEJ W PODKARPACKICH MIODACH ODMIANOWYCH
}

\begin{abstract}
Streszczenie
Celem pracy było porównanie aktywności diastazy w miodach odmianowych, a także ocena stabilności termicznej enzymu podczas rozpuszczania i długotrwałego przechowywania miodu. Materiał do badań stanowiło 25 miodów odmianowych pozyskanych z pasiek działających na terenie Podkarpacia, w tym wielokwiatowy, nawłociowy, rzepakowy, lipowy i spadziowy. Liczbę diastazową (DN) określono w miodach świeżych, długotrwale przechowywanych i poddanych ogrzewaniu za pomocą testu Phadebas Honey Diastase test. Najwyższą aktywność $\alpha$-amylazy stwierdzono w miodach nawłociowych i lipowych (odpowiednio: 32,65 i 31,47 DN), a najniższą - w miodach rzepakowych (15,32 DN), przy czym wszystkie badane próbki spełniały limit określony w obowiązujących przepisach. Miody ciemne charakteryzowały się wyższą aktywnością diastazy, współczynnik korelacji Pearsona (r) pomiędzy barwą (mierzoną w jednostkach absorbancji przy $\lambda=450 \mathrm{~nm}$ ) a liczbą diastazową miodu wyniósł 0,75 . Podczas przechowywania próbek miodu w temp. $20 \pm 2{ }^{\circ} \mathrm{C}$ przez 24 miesiące obserwowano obniżenie aktywności diastazy o $17 \div$ $42 \%$ w zależności od odmiany. Aktywność diastazy malała ze wzrostem temperatury rozpuszczalnika użytego do rozcieńczania miodu, przy czym enzym był stabilny w zakresie $20 \div 40{ }^{\circ} \mathrm{C}$, a po przekroczeniu temp. $60{ }^{\circ} \mathrm{C}$ stwierdzono drastyczną inhibicję jego aktywności. Ponadto roztwór miodu przechowywany w temp. $20 \pm 2{ }^{\circ} \mathrm{C}$ przez $24 \mathrm{~h}$ nie tracił aktywności enzymatycznej. Wykazano, że stosowanie miodu do słodzenia ciepłych (poniżej $60^{\circ} \mathrm{C}$ ) napojów nie powoduje całkowitej dezaktywacji diastazy.
\end{abstract}

Słowa kluczowe: miód, aktywność enzymatyczna, liczba diastazowa, podgrzewanie miodu

\section{Wprowadzenie}

Miód jest naturalną słodką substancją stosowaną od wieków nie tylko jako produkt spożywczy, ale także jako środek leczniczy wykazujący właściwości przeciwutle-

Mgr inż. M. Wesolowska, dr hab. inż. M. Dżugan, prof. nadzw., Katedra Chemii i Toksykologii Żywności, Wydz. Biologiczno-Rolniczy, Uniwersytet Rzeszowski, ul. Ćwiklińskiej 1a, 35-601 Rzeszów. Mgr inż. M. Wesołowska, Slovenská Pol'nohospodárska Univerzita v Nitre, Tr. A Hlinku 2, 94976 Nitra, Slovakia.Kontakt: mwesolowska@ur.edu.pl 
niające [16, 28], przeciwbakteryjne [12, 23] oraz przeciwzapalne [8]. Miód jest wytwarzany przez pszczoły (Apis mellifera) z nektaru roślin, wydzielin roślinnych i wydzielin owadów ssących. Ze względu na rodzaj pożytku pszczelego wyróżnia się miód nektarowy (wytwarzany z nektaru kwiatów), spadziowy (wytwarzany z wydzielin owadów ssących soki żywych części roślin lub wydzielin żywych części roślin) oraz miód nektarowo-spadziowy [19]. W składzie chemicznym miodu dominują głównie cukry proste: fruktoza i glukoza (ok. $80 \%$ ) i woda (ok. $17 \%$ ). O wartości biologicznej miodu decyduje jednak zawartość pozostałych składników (ok. $3 \%$ ), takich jak: białka, enzymy, aminokwasy, kwasy fenolowe, witaminy, oraz makro- i mikroelementy [13]. Skład miodu jest zmienny i zależy przede wszystkim od jego pochodzenia botanicznego [9, 11], ale także wielu czynników sezonowych i środowiskowych [24]. Ciemne miody zawierają więcej korzystnych składników i wykazują silniejszą aktywność przeciwutleniającą niż miody jasne $[5,28]$. Powszechnie przyjmuje się, że składniki roślin leczniczych mogą być przenoszone do miodu, co nadaje miodom odmianowym specyficznych właściwości leczniczych [15, 2].

Enzymy w miodzie pszczelim występują w ilościach minimalnych, ale są jego bardzo ważnymi składnikami, ponieważ decydują o procesach dojrzewania i aktywności biologicznej tego produktu. Enzymy występujące w miodzie pochodzą głównie z wydzielin gruczołów ślinowych pszczół, jednak niewielkie ilości mogą pochodzić również z ziaren pyłków lub spadzi [20]. Pszczoły zbieraczki zaczynają wzbogacać nektar lub spadź w enzymy już w trakcie lotu z terenów pożytkowych do ula. Kolejnym etapem wzbogacania miodu w enzymy jest proces jego dojrzewania, kiedy pszczoły ulowe przenoszą go do coraz wyższych części plastra [15]. Ilość enzymów dodanych przez pszczoły do miodu jest zależna nie tylko od stanu zdrowia i wieku pszczół, ale również od plonowania roślin [7]. Zawartość enzymów w miodzie może być mniejsza podczas intensywnego okresu pożytkowego, gdy pszczoły robotnice nie nadążają z wytwarzaniem miodu [3]. Obecność enzymów, takich jak $\alpha$ - i $\beta$-amylaza, katalaza, inwertaza, maltaza, glukooksydaza, kwaśna fosfataza i lizozym została potwierdzona w miodach odmianowych [13]. Są one uznawane za najmniej stabilne termicznie składniki wykorzystywane do kontroli jakości miodu. Uznanym wskaźnikiem jakości, uwzględnionym $\mathrm{w}$ polskich i międzynarodowych wymaganiach prawnych dotyczących miodu, jest $\alpha$-amylaza (diastaza), enzym odpowiedzialny za proces hydrolizy cukrów złożonych. Miód naturalny nie zawiera cukrów złożonych, obecność amylazy została jednak potwierdzona w większości badanych miodów, a funkcja tego enzymu w miodzie nie jest do końca poznana [29]. Prawdopodobnie występowanie tego enzymu w miodzie, który pszczoły gromadzą w plastrach jako pokarm dla rodziny pszczelej, jest niezbędne przede wszystkim dla rozwoju młodych pszczół, a nie w procesie dojrzewania miodu [29]. Niemniej jednak aktywność diastazy jest ważnym pa- 
rametrem jakości miodu, stosowanym w celu wykrycia przegrzania, fałszowania lub innych zabronionych zabiegów [18].

Aktywność diastazy ( $\alpha$-amylaza, EC 3.2.1.1) mierzona w skali Schade'a jako liczba diastazowa (DN, diastase number) jest definiowana jako ilość enzymu, która przekształca 0,01 grama skrobi w ciągu jednej godziny w temp. $40{ }^{\circ} \mathrm{C}$ [19]. Ostatnio wdrożono alternatywną procedurę z użyciem testu Phadebas ${ }^{\circledR}$ test tablets, wykorzystującą nierozpuszczalny zabarwiony substrat skrobiowy [17]. Test został zaakceptowany jako bardziej skuteczny do kontroli zafałszowania miodu amylazami obcego pochodzenia [26]. Liczba diastazowa w świeżym nieogrzewanym miodzie jest bardzo zróżnicowana również w obrębie tej samej odmiany, ale zgodnie z Dyrektywą UE [10] oraz Rozporządzeniem Ministra Rolnictwa i Rozwoju Wsi w sprawie jakości handlowej miodu nie może być mniejsza niż 8 DN [19]. Przyjmuje się, że aktywność amylazy drastycznie obniża się podczas podgrzewania miodu powyżej $45^{\circ} \mathrm{C}$, w związku z czym liczba diastazowa miodu może być wykorzystywana jako parametr jego jakości [14].

Celem pracy było określenie liczby diastazowej różnych odmian miodu, a także ocena wpływu termicznego przetwarzania i przechowywania miodu na aktywność diastazy.

\section{Material i metody badań}

Materiał do badań stanowiło 25 próbek miodów, w tym: wielokwiatowy (5), nawłociowy (5), rzepakowy (5), lipowy (5) i spadziowy (5). Miody pobrano bezpośrednio od pszczelarzy działających na terenie województwa podkarpackiego $\mathrm{w}$ sezonie pszczelarskim $2014 \mathrm{i}$ przechowywano $\mathrm{w}$ temp. $20 \pm 2{ }^{\circ} \mathrm{C} \mathrm{z}$ ograniczonym dostępem światła do czasu analiz. Klasyfikacja odmian miodu została dokonana przez pszczelarzy na podstawie barwy i dostępności poszczególnych pożytków. Liczbę diastazową oznaczano według metody uwzględnionej w Rozporządzeniu Ministra Rolnictwa i Rozwoju Wsi [19] za pomocą testu Phadebas Honey Diastase test (C) Magle AB Lund, Sweden 2010) zgodnie z załączoną procedurą. W tym celu $1 \mathrm{~g}$ miodu rozcieńczano w kolbie miarowej o poj. $100 \mathrm{~cm}^{3}$ 0,1 M buforem octanowym o pH 5,2. Następnie $5 \mathrm{ml}$ roztworu miodu podgrzewano w łaźni wodnej do temp. $40{ }^{\circ} \mathrm{C}$ i dodawano tabletkę testową. Całość inkubowano w łaźni wodnej w temp. $40^{\circ} \mathrm{C}$ przez $30 \mathrm{~min}$. Po tym czasie zatrzymywano reakcję enzymatyczną, dodając $1 \mathrm{ml} 0,5 \mathrm{M} \mathrm{NaOH}$. Roztwór sączono przez sączek bibułowy i mierzono absorbancję przesączu względem próby zerowej w spektrofotometrze (Biomate 3, ThermoScientific Inc., Waltham, MA, USA) przy długości fali $\lambda=620 \mathrm{~nm}$. Wyniki wyrażone jako DN (diastase number) odczytywano z tabeli przeliczeniowej dołączonej do testu. Oznaczenie powtórzono w miodach przechowywanych w temp. $20 \pm 2{ }^{\circ} \mathrm{C}$ przez 24 miesiące. W celu określenia stabilności termicznej diastazy wybrane próbki miodu (z każdej odmiany o najwyższej aktywności wyjściowej badanego enzymu) rozpuszczano w 0,1 M buforze octanowym (pH 5,2) 
o wzrastającej temperaturze $\left(20,40,60,70,80 \mathrm{i} 100^{\circ} \mathrm{C}\right)$, po czym roztwory schładzano do temp. $20 \pm 2{ }^{\circ} \mathrm{C}$ i oznaczano liczbę diastazową według standardowej procedury. Dodatkowo, w celu sprawdzenia stabilności diastazy po 100-krotnym rozcieńczeniu miodu buforem o optymalnym $\mathrm{pH}$ i temp. $20^{\circ} \mathrm{C}$, roztwory przechowywano przez $24 \mathrm{~h}$ w temp. $20 \pm 2{ }^{\circ} \mathrm{C}$, a następnie powtarzano oznaczanie liczby diastazowej. Intensywność barwy badanych miodów analizowano metodą spektrofotometryczną na podstawie pomiaru absorbancji 50-procentowych $(\mathrm{m} / \mathrm{v})$ wodnych roztworów miodu (odwirowanych przy $14000 \times \mathrm{g}, 10 \mathrm{~min})$ przy długości fali $\lambda=450 \mathrm{~nm}\left(\mathrm{~A}_{450}\right)$. Wszystkie analizy wykonano $\mathrm{w}$ dwóch powtórzeniach, a współczynnik powtarzalności wyliczony zgodnie z Rozporządzeniem Ministra Rolnictwa i Rozwoju Wsi [19] nie przekraczał wartości 0,063 . Liczbę diastazową miodów korelowano z ich barwą $\left(\mathrm{A}_{450}\right)$, wyznaczając współczynnik korelacji liniowej Pearsona (r). Istotność różnic między wartościami średnimi parametrów poszczególnych odmian miodu oraz będących wynikiem przechowywania miodów zweryfikowano jednoczynnikową analizą wariancji (ANOVA) $\mathrm{z}$ testem Tukeya $(\mathrm{p}<0,05$. Analizy statystyczne wykonano w programie Statistica 13 (StatSoft Polska, 2013).

\section{Wyniki i dyskusja}

W analizowanych próbkach miodów odmianowych pochodzących z terenu Podkarpacia oznaczono wartość liczby diastazowej bezpośrednio po pobraniu w pasiece oraz po 24 miesiącach przechowywania w temp. $20 \pm 2{ }^{\circ} \mathrm{C}$ (tab. 1). Wszystkie badane miody spełniały limity określone $\mathrm{w}$ obowiązujących regulacjach prawnych [10, 19]. Spośród badanych odmian miody nawłociowe, lipowe i spadziowe charakteryzowały się największą aktywnością $\alpha$-amylazy ( $\mathrm{p}<0,05)$ odpowiednio [DN]: 32,65, 31,47 i 27,92. Najniższą liczbę diastazową stwierdzono w miodach rzepakowych (15,32 DN). Ponadto wykazano, że ciemne miody charakteryzowały się wyższą aktywnością diastazową niż miody jasne, o czym świadczy współczynnik korelacji $(r=0,75)$ pomiędzy barwą miodu $\left(\mathrm{A}_{450}\right)$ a jego liczbą diastazową.

Uzyskane wyniki są porównywalne do podawanych przez innych autorów badających miody o różnym pochodzeniu geograficznym. Kowalski i wsp. [14] wykazali w polskich miodach spadziowych liczbę diastazową na poziomie $18,0 \div 23,2 \mathrm{DN}$. Vorlov i Pridal [27] uzyskali niższe wyniki w czeskich miodach kwiatowych $(11,24 \div$ 30,3 DN), a wyższe w miodach spadziowych $(13,6 \div 45,4$ DN). Tosi i wsp. [25] stwierdzili w argentyńskich miodach wielokwiatowych liczbę diastazową na poziomie $11,2 \div 25,8 \mathrm{DN}$. Wpływ odmiany miodu na aktywność diastazy potwierdzają również badania innych autorów [3, 17].

Przechowywanie próbek miodu w temp. $20 \pm 2{ }^{\circ} \mathrm{C}$ przez 24 miesiące spowodowało nieznaczne zmniejszenie aktywności diastazy, średnio o ok. $31 \%$ (tab. 1). Największe, statystycznie istotne $(\mathrm{p}<0,05)$ obniżenie aktywności amylazy zaobserwowano 
w przypadku miodów lipowych i nawłociowych (o 42 i $37 \%$ ), najmniejsze zaś w przypadku miodów rzepakowych (17\%). Odmiana miodu istotnie wpływała na stabilność diastazy, co zostało potwierdzone w badaniach własnych. Sancho i wsp. [21] zaobserwowali, że przechowywanie hiszpańskiego miodu przez 28 miesięcy w temp. $20 \pm 2{ }^{\circ} \mathrm{C}$ spowodowało obniżenie aktywności amylazy w miodach wrzosowych o 72,7 $\pm 9,8 \%$, w miodach koniczynowych o $56,3 \pm 11,6 \%$, podczas gdy w miodach eukaliptusowych o $34,3 \pm 13,6 \%$. W badaniach leśnego miodu nepalskiego wykazano dużo większe straty diastazy podczas 8-miesięcznego przechowywania miodów, obniżenie liczby diastazowej wyniosło ok. $65 \%$ [22].

Tabela 1. Aktywność diastazowa miodów świeżych i przechowywanych 24 miesiące [DN]

Table 1. Diastatic activity of fresh and 24 month stored honey samples [DN]

\begin{tabular}{||c|c|c|c||}
\hline $\begin{array}{c}\text { Odmiana miodu } \\
\text { Variety of honey }\end{array}$ & $\begin{array}{c}\text { Miody świeże } \\
\text { Fresh honey }\end{array}$ & \multicolumn{2}{|c||}{$\begin{array}{c}\text { Miody przechowywane przez 24 miesiące } \\
\text { Honey stored for 24 months }\end{array}$} \\
\hline $\begin{array}{c}\text { Wielokwiatowy } \\
\text { Multifloral }\end{array}$ & $22,15 \pm 8,20$ & $15,45 \pm 6,95$ & $\downarrow 30 \%$ \\
\hline $\begin{array}{c}\text { Lipowy } \\
\text { Tilia }\end{array}$ & $31,99^{\mathrm{a}} \pm 9,60$ & $18,53^{\mathrm{b}} \pm 3,03$ & $\downarrow 42 \%$ \\
\hline $\begin{array}{c}\text { Nawłociowy } \\
\text { Goldenrod }\end{array}$ & $33,08^{\mathrm{a}} \pm 3,34$ & $20,92^{\mathrm{b}} \pm 5,98$ & $\downarrow 37 \%$ \\
\hline $\begin{array}{c}\text { Rzepakowy } \\
\text { Rape }\end{array}$ & $15,35 \pm 1,58$ & $12,75 \pm 2,86$ & $\downarrow 17 \%$ \\
\hline $\begin{array}{c}\text { Spadziowy } \\
\text { Honeydew }\end{array}$ & $27,92^{\mathrm{a}} \pm 5,41$ & $19,50^{\mathrm{b}} \pm 3,34$ & $\downarrow 30 \%$ \\
\hline \hline
\end{tabular}

Objaśnienia / Explanatory notes:

W tabeli przedstawiono wartości średnie \pm odchylenia standardowe / Table shows mean values \pm standard deviations; $\mathrm{a}, \mathrm{b}$ - wartości średnie oznaczone różnymi literami różną się statystycznie istotnie $(\mathrm{p}<0,05)$ / mean values denoted by different letters differ statistically significantly $(\mathrm{p}<0.05)$;

$\downarrow$ - obniżenie aktywności diastazowej / decrease in diastatic activity.

Stabilność termiczna diastazy podczas rozpuszczania miodu w podwyższonych temperaturach $\left(40 \div 100{ }^{\circ} \mathrm{C}\right)$ była podobna we wszystkich analizowanych odmianach miodu (rys. 1). Brak zmian aktywności diastazy obserwowano w temperaturze rozpuszczania nieprzekraczającej $40{ }^{\circ} \mathrm{C}$, podczas gdy wyższe temperatury powodowały inhibicję enzymu. Największą inhibicję aktywności $\alpha$-amylazy w temp. $60{ }^{\circ} \mathrm{C}$ obserwowano w miodzie lipowym (o ok. $20 \%$ ), a miód rzepakowy był najbardziej wrażliwy na działanie wysokiej temperatury, w temp. $60^{\circ} \mathrm{C}$ aktywność amylazy obniżała się o ok. $50 \%$. Zastosowanie wyższych temperatur (powyżej $80{ }^{\circ} \mathrm{C}$ ) powodowało całkowitą dezaktywację enzymu we wszystkich badanych próbkach miodów. Analogiczne wyniki uzyskali Tosi i wsp. [25], którzy stwierdzili obniżenie aktywności diastazy o ok. $20 \%$ podczas podgrzewania miodu wielokwiatowego do $60{ }^{\circ} \mathrm{C}$ i niemal całkowi- 
tą dezaktywację amylazy przy podgrzaniu miodów do $90{ }^{\circ} \mathrm{C}$. Dodatkowo cytowani autorzy wykazali, że wydłużenie czasu ogrzewania próbki (od 120 do 1200 s) wpływa nieznacznie ujemnie na aktywność amylolityczną miodu i zasugerowali, że największy ubytek tego enzymu następuje na początku ogrzewania. Kowalski i wsp. [14] dowiedli, że podgrzanie miodu za pomocą promieniowania mikrofalowego do temp ok. $80{ }^{\circ} \mathrm{C}$ powoduje zmniejszenie liczby diastazowej o ok. $35 \%$. Ramirez Cervantes i wsp. [18] stwierdzili obniżenie tej liczby o 6,8 i 2,5 DN w dwóch miodach ogrzewanych w temp. $55^{\circ} \mathrm{C}$ przez 15 min. Bogdanov [6] wykazał, że obróbka cieplna miodu nie powinna przekraczać 31 dni w temp. $40{ }^{\circ} \mathrm{C}$, jednak może ona zostać skrócona do $2 \mathrm{~h} w$ temp. $80^{\circ} \mathrm{C}$ bez znaczącego zmniejszenia aktywności diastazy. $\mathrm{Z}$ drugiej strony wykazano, że skrócenie czasu upłynniania miodu przez podwyższanie temperatury procesu powoduje powstawanie niepożądanego 5-hydroksymetylofurfuralu [1, 4, 14].

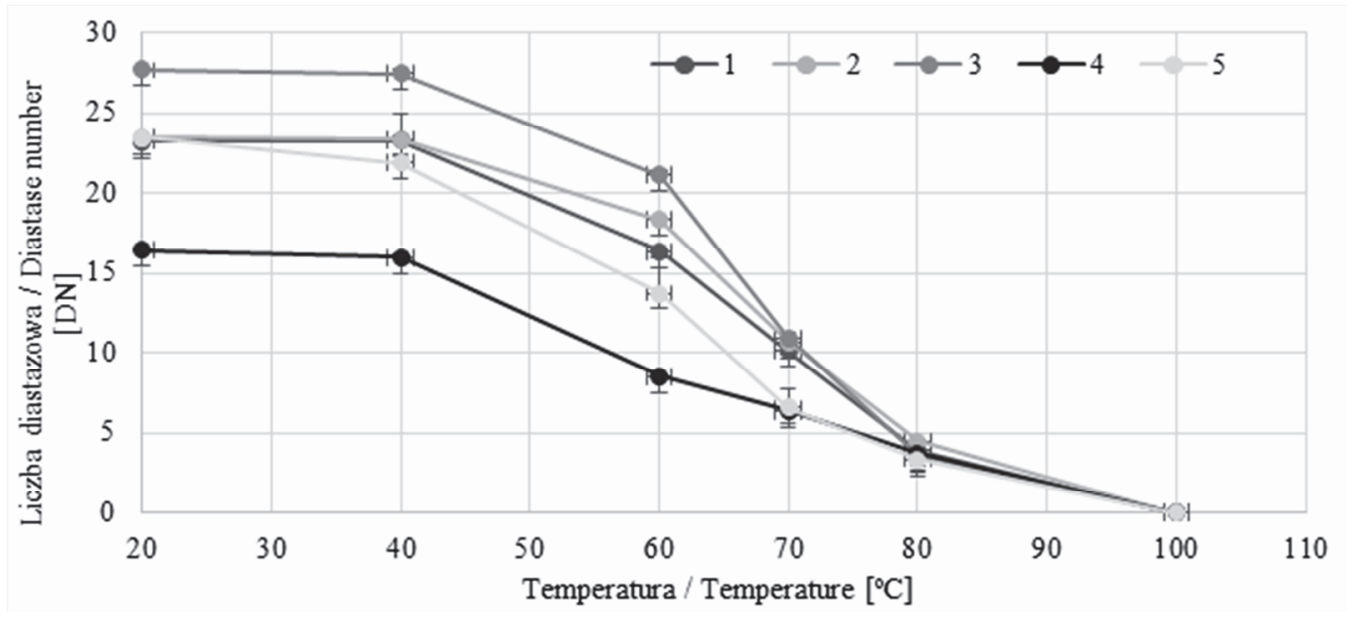

Objaśnienia / Explanatory notes:

1 - miód wielokwiatowy / multifloral honey, 2 - miód lipowy / tilia honey, 3 - miód nawłociowy / goldenrod honey, 4 - miód rzepakowy / rape honey, 5-miód spadziowy / honeydew honey

Rys. 1. Stabilność termiczna diastazy występującej w miodach odmianowych podczas rozpuszczania w buforze octanowym (pH 5,2) o różnej temperaturze

Fig. 1. Thermal stability of diastase present in varietal honey while dissolving it in acetate buffer $(\mathrm{pH} 5.2)$ at different temperatures

Na podstawie analizy aktywności diastazy w roztworze miodu (100-krotnie rozcieńczonym), w optymalnym $\mathrm{pH}$, po 24-godzinnym przechowywaniu w temp. $20 \pm$ $2{ }^{\circ} \mathrm{C}$ wykazano nieznaczne obniżenie aktywności enzymu niezależne od odmiany miodu (p < 0,05) (rys. 2). Kędzia i Hołderna-Kędzia [13] dowiedli, że rozcieńczenie miodu wodą pozwala na uzyskanie znacznie większej aktywności przeciwbakteryjnej w po- 
równaniu z tą wynikającą z dużego stężenia cukrów w miodzie. Spostrzeżenia te zwróciły uwagę badaczy na antybiotyczne składniki enzymatyczne, do których zalicza się: oksydazę glukozy i lizozym. Z badań własnych wynika, że amylaza nie jest składnikiem miodu, którego zawartość wzrasta podczas rozcieńczania miodu.

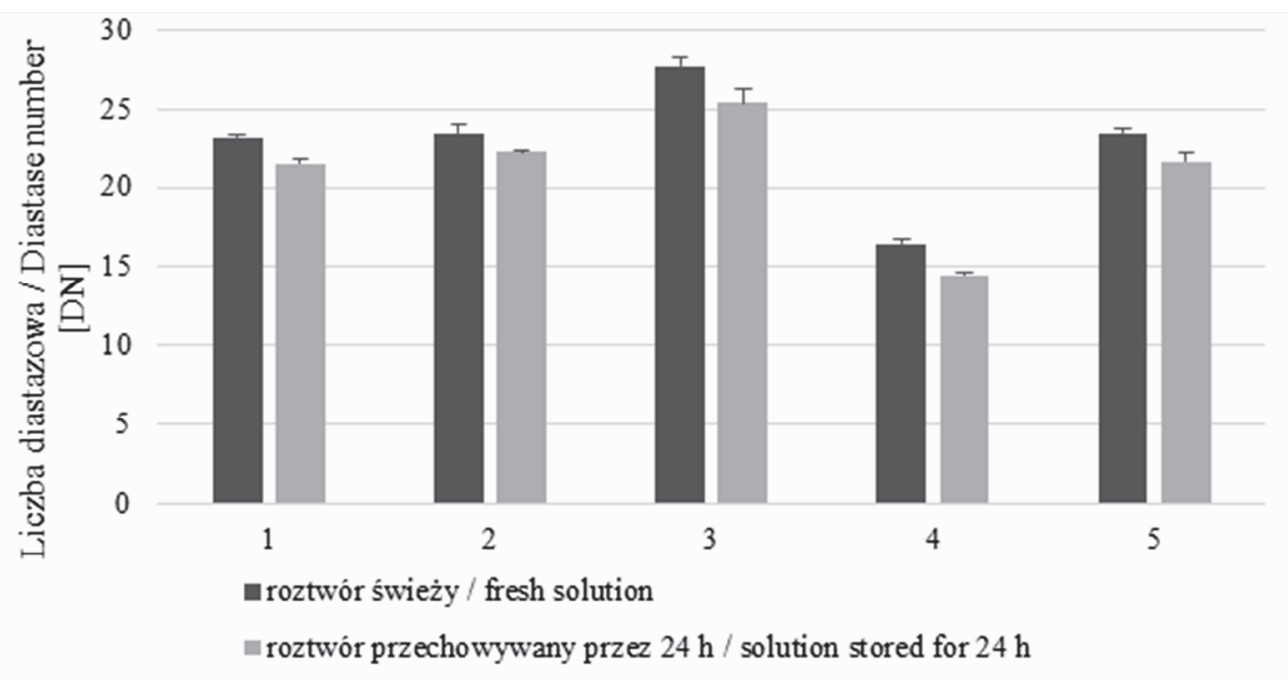

Objaśnienia jak pod rys. 1. / Explanatory notes as in Fig. 1.

Rys. 2. Wpływ przechowywania 100-krotnie rozcieńczonego roztworu miodu na jego aktywność diastazową - w temp. $20 \pm 2{ }^{\circ} \mathrm{C}$ przez $24 \mathrm{~h}$

Fig. 2. Effect of storing hundredfold diluted honey solution at temperature $20 \pm 2{ }^{\circ} \mathrm{C}$ for $24 \mathrm{~h}$ on its diastatic activity

Liczba diastazowa jest ważnym parametrem jakości miodu, będącym wskaźnikiem jego enzymatycznej aktywności. Zgodnie z obowiązującymi przepisami powinna być ona wyższa od $8[10,19]$. Krajowe miody dobrej jakości w zależności od odmiany charakteryzują się wysoką aktywnością enzymatyczną, a ich liczba diastazowa jest często wyższa od 20. Ustalenie granicznych wartości tego parametru w krajowych miodach odmianowych jest szczególnie istotne dla kontroli jakości produktów obecnych na polskim rynku, a obniżenie liczby diastazowej miodu powinno być traktowane jako jego zafałszowanie. Niska wartość liczby diastazowej może wskazywać na niewłaściwie przeprowadzoną dekrystalizację miodu, ale także świadczyć o celowym dodaniu do miodu syropów cukrowych lub podkarmianiu nimi pszczół [30]. W badaniach własnych wykazano, że nie tylko aktywność, ale i stabilność termiczna diastazy jest zróżnicowana odmianowo, co może ograniczać przydatność tego parametru do identyfikacji miodów poddanych obróbce termicznej. 


\section{Wnioski}

1. Aktywność diastazy była zróżnicowana i zależna od odmiany miodu, przy czym miody ciemne wykazywały wyższą liczbę diastazową niż miody jasne.

2. Świeże miody podkarpackie charakteryzowały się wysoką liczbą diastazową, która zmniejszała się podczas długotrwałego przechowywania miodów, ale w żadnymprzypadku nie stwierdzono przekroczeń limitu ustalonego w regulacjach prawnych.

3. Diastaza ( $\alpha$-amylaza EC 3.2.1.1) miodu wykazuje bardzo dobrą stabilność termiczną w zakresie temperatur $20 \div 40{ }^{\circ} \mathrm{C}$. Drastyczna inhibicja aktywności zachodzi w wyższych temperaturach, powyżej $60{ }^{\circ} \mathrm{C}$, co potwierdza możliwość użycia miodu do słodzenia ciepłych, ale nie gorących napojów z zachowaniem jego aktywności diastazowej.

Źródlo finansowania: PB KChTŻ/2016

\section{Literatura}

[1] Al-Diab D., Jarkas B.: Effect of storage and thermal treatment on the quality of some local brands of honey from Latakia markets. J. Ent. Zoology Stud., 2015, 3 (3), 328-334.

[2] Alvarez-Suarez J.M., Gasparrini M., Forbes-Hernández T.Y., Mazzoni L., Giampieri F.: The composition and biological activity of honey: A focus on Manuka honey. Foods, 2014, 3, 420-432.

[3] Amri A., Ladjama A.: Enzymes activities, hydroxymethylfurfural content and pollen spectrum of some Algerian honey. Afr. J. Agric. Res., 2015, 10 (7), 613-622.

[4] Amsiejus A., Danilcenko H., Jariene E., Jeznach M., Kulaitiene J.: Consumer assessment of varietal honeys and effect of thermal liquefaction of the product on some of its qualitative parameters. J. Apic. Sci., 2012, 55 (1), 5-13.

[5] Bertoncejl J., Dobersek U., Jamnik M., Golob T.: Evaluation of the phenolic content, antioxidant activity and colour of Slovenian honey. Food Chem., 2007, 105, 822-828.

[6] Bogdanov S.: Liquefaction of honey. Apiacta, 1993, XXVIII, 4-10.

[7] Da Silva P.M., Gauche C., Gonzaga L.V., Costa A.C.O., Fett R.: Honey: Chemical composition, stability and authenticity. Food Chem., 2016, 196, 309-323.

[8] Devasvaran K., Yong Y.K.: Anti-inflammatory and wound healing properties of Malaysia Tualang honey. Curr. Sci., 2013, 110 (1), 47-51.

[9] Dezmirean G.I., Mărghitaş L.A., Bobiş O., Dezmirean D.S., Bonta V., Erler S.: Botanical origin causes changes in nutritional profile and antioxidant activity of fermented products obtained from honey. J. Agric. Food Chem., 2012, 60, 8028-8035.

[10] Dyrektywa Rady 2001/110/WE z dnia 20 grudnia 2001 r. odnosząca się do miodu. Dz. Urz. UE L 10, ss. 47-52, z 12.01.2002 z późn. zm.

[11] Isnandia A.A., Tania M.S., Celso A.C., Neide Q., Marciane M.J., Luiz E.B., Edeltrudes O.L., Antonia L.S., Antonio G.S.: Phenolic profile, antioxidant activity and palynological analysis of stingless bee honey from Amazonas, northern Brazil. Food Chem., 2013, 14, 3552-3558. 
[12] Kačániová M., Vukovic N., Bobková A., Fikselová M., Rovná K., Haščík P., Čuboň J., Hleba L., Bobko M.: Antimicrobial and antiradical activity of Slovakian honeydew honey samples. JMBFS, 2011, 1 (3), 354-368.

[13] Kędzia B., Hołderna-Kędzia E.: Miód - skład i właściwości biologiczne. Przedsiębiorstwo Wydawnicze „Rzeczpospolita” S.A., Warszawa 2008.

[14] Kowalski S., Lukasiewicz M., Bednarz Sz., Panuś M.: Diastase number changes during thermal and microwave processing of honey. Czech J. Food Sci., 2012, 30 (1), 21-26.

[15] Krell R.: Value-added Products from Beekeeping. FAO Agricultural Services Bulletin No. 124. Food and Agriculture Organization of the United Nations, Rome 1996.

[16] Majewska E., Trzanek J.: Właściwości przeciwutleniające miodów wielokwiatowych i innych produktów pszczelich. Bromat. Chem. Toksykol., 2009, XLII (4), 1089-1094.

[17] Persano O.L., Pulcini P.: A scientific note on the Phadebas method for honeys with low enzyme content. Apidologie, 1999, 30, 347-348.

[18] Ramírez Cervantes M.A., Gonzalez Novelo S.A., Sauri Duch E.: Effect of the temporary thermic treatment of honey on variation of the same during storage. Apiacta, 2000, 35 (4), 162-170.

[19] Rozporządzenie Ministra Rolnictwa i Rozwoju Wsi z dnia 3 października 2003 r. w sprawie szczegółowych wymagań w zakresie jakości handlowej miodu. Dz. U. 2003 r. Nr 181, poz. 1773.

[20] Sakac N., Sak-Bosnar M.: A rapid method for the determination of honey diastase activity. Talanta, 2012, 93, 135-138.

[21] Sancho M.T., Muniategui S., Huidobro J.F., Lozano J.S.: Aging of honey. J. Agric. Food Chem., 1992, 1002 (40), 134-138.

[22] Shelear H.H.: Effect of storage and processing temperatures on honey quality. J. Babylon Univ. Pure Appl. Sci., 2012, 21 (6), 2244-2253.

[23] Sowa P., Grabek-Lejko D., Wesołowska M., Swacha S., Dżugan M.: Hydrogen peroxide- dependent antibacterial action of Melilotus albus honey. Lett. App. Microbiol., 2017, 65, 82-89.

[24] Sullivan A., Callaghan Y., Connor T., Brien N.: Comparison of the antioxidant activity of commercial honeys, before and after in vitro digestion. Pol. J. Food Nutr. Sci., 2013, 63, 167-171.

[25] Tosi E., Martinet R., Ortega M., Lucero H., Re E.: Honey diastase activity modified by heating. Food Chem., 2008, 106, 883-887.

[26] Voldrich M., Rajchl A., Čížková H., Cuhra P.: Detection of foreign enzyme addition into the adulterated honey, Czech J. Food Sci., 2009, 27, S280-S282.

[27] Vorlov L., Piidal A.: Invertase and diastase activity in honeys of Czech provenience. Acta Univ. Agric. Silvic. Mendelianae Brunensis, 2002, 8 (5), 57-65.

[28] Wesołowska M., Dżugan M.: The use of the Photochem device in evaluation of antioxidant activity of Polish honey. Food Anal. Method., 2017, 10 (5), 1568-1574.

[29] White J.W. Jr: Quality evaluation of honey: Role of HMF and diastase Assays. Am. Bee J., 1992, 132 (11), 737-743.

[30] Zábrodská B., Vorlová L.: Adulteration of honey and available methods for detection - a review. Acta Vet. Brno, 2014, 83, S85-S102.

\section{ACTIVITY AND THERMAL STABILITY OF DIASTASE PRESENT IN HONEY FROM PODKARPACIE REGION}

\section{S u m m a r y}

The objective of the research study was to compare the activity of diastase in varietal honey as well as to evaluate the thermal stability of the enzyme during dissolving and long-term storing honey. The 
study material consisted of 25 varietal honeys from apiaries located in the Podkarpacie region including multifloral, goldenrod, rape, tilia, and honeydew honeys. The diastase number (DN) was determined using a Phadebas Honey Diastase test in fresh, long-term stored and heated honeys. The highest activity of $\alpha$-amylase was found for the goldenrod and tilia honeys (32.65 and 31.47 DN, respectively), the lowest for the rapeseed honey $(15.32 \mathrm{DN})$ All the tested samples met the limits as specified in the regulations in force. The dark honeys were characterized by a higher diastatic number than the light honeys, and the Pearson's correlation coefficient between the colour (measured as an absorbance unit with $\lambda=450 \mathrm{~nm}$ ) and the diastase number was 0.751 . While storing the honey samples at a temperature of $20 \pm 2{ }^{\circ} \mathrm{C}$ for a period of 24 months, a 17 to $42 \%$ decrease in the diastase activity was reported depending on the variety. The diastase activity decreased with the increasing temperature of solvent used to diluted the honey, whereas the enzyme remained stable in the temperature range between 20 and $40{ }^{\circ} \mathrm{C}$. As soon as the temperature of $60^{\circ} \mathrm{C}$ was exceeded, a drastic inhibition of the enzyme activity was reported. In addition, the honey solution, stored at $20 \pm 2{ }^{\circ} \mathrm{C}$ for 24 hours, did not lose enzymatic activity. It was proved that the honey used to sweeten warm (below $60{ }^{\circ} \mathrm{C}$ ) beverages did not completely deactivate the diastase.

Key words: honey, enzymatic activity, diastase number, heating up honey 